When his subjects were on the House floor, he would scurry to the galleries to check up on their perambulations (because people in the visitors galleries aren't allowed to take notes, he would hide slips of paper in his socks, reaching down surreptitiously to jot notes). His subjects were so well trained that one of them, about to exit the chamber, turned toward the gallery, cupped his hands, and said in a quite audible voice, "I'm going to the bathroom!"

A 1973 article in American Politics Quarterly summarized his findings and suggested what a landmark study he had undertaken.

Dave launched his teaching career at Dartmouth College (1962-1968). Later he taught at the University of North Carolina (1968-1973), Duke University (1976), and the University of Maine at Orono (1977-1984). A unforgettable teacher, he challenged his students to think in new ways about politics but never coddled them (he was a demanding grader). At Dartmouth, he and his colleague Roger Davidson offered presidentialyear seminars in which students designed, implemented, and analyzed surveys replicating classic voting studies. For the 1968 primary the students braved icy roads to cover sample precincts over the entire state of New Hampshire. The result turned out to be the best prediction of the momentous Democratic primary. President Lyndon Johnson, who expected to capture 70-75 percent of the vote, was the choice of only about half of the respondents; yet only 20 percent were antiwar "peaceniks." The remaining 30 percent were still on the fence. Such results confounded the media gurus, whose polls told them Johnson would win in a walk. But the survey was light on the mark: although Johnson won the popular-vote "beauty contest" with 49 percent, the undecided voters sided overwhelmingly with antiwar voters to give 42 percent to challenger Eugene McCarthy. It was rightly interpreted as a stunning defeat for the president, the rest, as they say, is history.

At Dartmouth, Dave also co-directed an unprecedented survey of House members and their attitudes toward congressional reform. Spon- sored by the Public Affairs Center and aided by an able corps of Dartmouth undergraduates, the study included interviews with a basic sample of 88 Representatives and a leader oversample, 102 lawmakers in all-one of the largest congressional surveys ever attempted. With his colleagues, he testified before the 1965 Joint Committee on the Organization of Congress and the next year published the results (Davidson, Kovenock, and O'Leary, Congress in Crisis, 1966).

His research skills led him back to Chapel Hill, where he was named co-principal investigator for several large-scale studies, the most notable of which was the elaborate Comparative State Elections Project (19681974), underwritten by the Ford Foundation. Because even national elections (1968, in this case) are actually collections of state contests, the project involved parallel surveys of voting-age citizens nationally and in thirteen selected states. Results were published as Explaining the Vote: Presidential Choices in the $\mathrm{Na}$ tion and the States, 1968 (Kovenock, Prothro et al, 1973). Other projects he helped direct were the 1972 American National Election Study and a pilot study of public opinion on national priorities (1972-1974).

Dave's sharp insight into survey data is perhaps best illustrated by an unpublished research note ("Responsible Voting and Responsible Analysis," 1977) that explains how citizens' knowledge appears quite different, depending on whether respondents are asked to volunteer a candidate's name or to pick it from a list of names presented. A simple, straightforward observation now accepted as commonplace; but he was perhaps the first to point out that commonly-used measures may understate citizens' knowledge levels. In 1977 Dave returned to New England to direct the Social Science Research Institute at the University of Maine (1977-1984). During his years there he authored or coauthored at least twenty three reports on a wide variety of subjects. In 1984 he joined Northeast Research, Inc., in Orono, and four years later became president and co-owner of the firm with his wife, Nancy W. Bauer. There he published some thirteen studies and prepared numerous others for a wide range of clients.

Dave's untimely passing leaves not only his family, to whom he was devoted, but a host of former colleagues and students who will always remember him with special affection. Donations for the David Kovenock Scholarship may be made to the University of Wisconsin Foundation, 1848 University Avenue, Madison WI 53708.

Roger Davidson

University of Maryland

Daniel Kovenock

Purdue University

\section{Joyce M. Mitchell}

Joyce M. Mitchell died May 28th, 1996, after a long struggle with an often debilitating illness. Her friends remember her as a gifted person, one who was an intellectual catalyst for students and colleagues and, simultaneously, a political catalyst for women at the University of Oregon and in the discipline of Political Science during the difficult and defining early days of the Womens' Movement in academia. Her formal academic accomplishments were substantial: B.A. Magna Cum Laude from Pomona (1952); M.A. from Berkeley (1954); a Congressional Fellowship (1957-58); Ph.D. from Berkeley (1964); numerous papers and reports dealing with aspects of American political life and with the status of women in academia; and a major text (co-authored with William C. Mitchell) introducing a generation of scholars to the power of a political economy perspective on American political processes.

As with many gifted scholars, however, Mitchell's life was multi-dimensional, characterized not only a formidable scholarly commitment, but also a deep involvement with current political and social issues. She was a witty, energetic and always informed critic of scholarly ideas that have little grounding in real political and social life, and political activism uninformed by the best of scholarly thought. We are among her friends, all of us influenced in important but somewhat different ways by her life, who feel that the best way to convey the richness, complexity and impact 
of that life is to recount, however briefly, some memories of our own.

Joan Acker: Joyce Mitchell was a vibrant, funny, highly intelligent, dedicated, and courageous person. She and I became friends in the 1960s in the anti-Vietnam War movement and a little later as coconspirators in the beginning of the women's movement. We were among the very few women faculty at the University of Oregon, which provided neither institutional support nor approval of our feminist activities at that time. Joyce was the primary mover of a study on the status of women at the University that we did in 1969. In addition to devising an unassailable research methodology for the study, she cleverly commandeered office space for the study from the political science department. Soon after that, led by Joyce, we few feminists began a campaign for an Affirmative Action office at the University. This was before such offices were required by HEW. We were strenuously opposed by the university; I remember Joyce as a tremendously articulate fighter who would not be intimidated by the University's top lawyer. And she did not have tenure yet. When our first Affirmative Action Director resigned because the University administration gave her no support, Joyce was the first one to support the director, identify the real problem and make it public. In all of these actions, she was superbly informed and politically skilled.

Joyce was also, for me, a model in her relationships with students. She was both demanding and supportive. Such support was tremendously important in the 1960 s and early $1970 \mathrm{~s}$ when there were so few women faculty, so few women graduate students, and the academic climate was frigid for women.

In the long years of her illness, Joyce's commitment to the women's movement and to other things in which she believed never weakened. Often she was too sick to take part, but she was always a supporter. And Joyce never lost her irreverent, quirky sense of humor. She faced her illness with great courage. She was a remarkable person.

Lois Bronfman and Rachel Starr. Joyce Mitchell was a mentor, friend, nurturer, nudge, warrior chief, a woman and a scholar, a Renaissance person of taste whose contribution to the profession of political science (which she loved) is probably not well understood. To us, she gave respect, encouraged our individual voices (not all women sounded alike to her), and demanded that we strive to be all that we could be at a time in which such support was reluctantly given. We love her. The memory of her strength and of her combative, lucid, erudite analyses of every aspect of her life-from baby monitors to public opinion to ballet-sustains and challenges us daily. We miss the possibility of her unexpected calls.

Dan Goldrich. In Eugene for a job interview in 1963, I met Joyce. I encountered her friendly interest in a visitor's ideas, one working very differently from her but for whom she had a warm, encouraging interest in the days long before I understood what "support" meant. I came to see her as my best educated colleague. But that important quality recedes in the presence of another. Among so many others, I came to be one touched by her characteristic animation. Over the years, I saw her give that gift-in the form of a hardworking, masterfully crafted intelligence, exquisitely sensitive to the ways power was used and abused, working through her unlimited capacity to care-bracing and encouraging her fellow strugglers for fairness, for a decent life, regarding Vietnam, wealth, race and gender.

Joyce had a gift for life in the garden, in the kitchen, for the basset at the end of her leash, in the canvas on her walls or the clay on her table, or the quality of sociability suffusing her and Bill's home.

Her animation had the dimension of challenge. She left us with the challenge of her long years of personal struggle- how to understand and respond to the struggle of a person beset by demons of the mind, of body, demons that we in our latetwentieth century lives don't yet know how to respond to. We don't yet know, but having known Joyce, we must try to learn.

Jerry Medler. Joyce Mitchell was my friend and although I never took a course from her, she was also my teacher. Good friends and good teachers are rare, Joyce was doubly rare. What I cherish most in my memories of Joyce was the seamless, integrated way in which she addressed life. This was her most simple but most challenging lesson for me.

Joyce could move from field to field with intellectual grace and when she wished, she could leave the academy (and our sometimes arcane concerns) to embrace other loves yet she never changed her style: always vigorous, always exciting and usually surprising. Joyce enjoyed a theoretical discussion but at heart she was an unflinching realist. Joyce truly liked politics and politicians (not all of course) yet she had a deep concern for art, music, dance, literature, history and athletics. She was a modern woman in every sense of the word yet she had a strong connection to tradition and community. For Joyce, these myriad interests were not really separate parts of her life. For me, everything she touched with her intellect became connected, clear and understandable. I miss that.

Mary Beth Medler. Joyce was the first person I met in Eugene. I was 21 years old, without a college degree and terribly insecure. Professor Joyce Mitchell, Ph.D. was an academic and an intellectual. She and Bill welcomed me and my husband, a new political science graduate student, to their home and served us a dinner of hot dogs and beans in honor of Independence Day. Just as that simple menu became a gourmet meal remembered in detail 33 years later, the vibrant intelligence of Joyce's spirit remains and sustains me today. After that first evening with Joyce, political science was no longer an abstract discipline. It was alive and exciting, something to argue about and defend and hold to standards so that the world was not only more knowable, but more interesting and better too.

Joyce, never patronizing but by forceful example, made a way for me in this world. That first night I found myself giving opinions barely formed and never articulated but awakened by her excitement and playful discourse. Because of Joyce I too could give voice ... and it was fun. 
It was also the seeds of feminism. The empowerment of a feminist voice, a feminist perspective. The Joyce that planted these seeds is the one I will always remember and honor. I hope I can be forgiven for my apparent insensitivity to another Joyce, one that I now know must have been much more vulnerable than I would/could allow. I continued to argue and debate with her and to be challenged by her insights and ideas. A vibrant, generous, wonderfully alive being, Joyce remains a true inspiration, a personal hero.

John Orbell. Joyce was an intellectual "older sister" for me. As such, she was a guaranteed source of good humored and informed, but unrelenting criticism of my own efforts to make scholarly sense out of the world. There was no way I could escape. Her wit and intelligence, and-with her husband Bill-the effervescent social context she provided for me as for many in the University community (the closest to a salon I have ever known) were magnetic. Still more compelling was the complement she paid me of taking my ideas seriously. I did not fully realize, in my first few years at the University, that Joyce was a rarity in the academic world who took everyone's ideas seriously; but no matter. I could not brush her theoretical, methodological and substantive criticisms off as, somehow, the product of a too-competitive academic context; it was impossible for me not to change my own thinking in response.

Beyond that, through her activist involvement with the profession of Political Science, she reinforced and elaborated my own appreciation that how academic pursuits are organized and conducted matters - matters because power relationships within a profession influence both the careers and the ideas that survive. I came to appreciate that Joyce's intellectual courage in adopting non-conformist and often unpopular (but, in retrospect, prescient) intellectual perspectives was the flip side of her courage as an activist on behalf of women and minorities in the discipline (no less prescient, as it turns out). The complementarity between these two parts of her life was not always straightforward: The intellectual perspective she adopted was occasionally unpopular among her political allies, just as her political perspective was occasionally -sometimes more than occasionally-unpopular among her intellectual allies.

The demands of her struggle with her own health, eventually and tragically, diverted her own extraordinary intellectual and political energies. The impact she had on her friends, on the University of Oregon, and on Political Science-as a scholarly discipline and as a political organization-will, nevertheless, remain.

\section{Fauneil J. Rinn}

Fauneil Rinn, a member of the political science department at San Jose State University since 1960, died from cancer on November 24, 1995. She was sixty-nine.

Fanny was trained in three fields: English (B.A., University of Cincinnati, 1956), journalism (M.S., Columbia University, 1947), and political science (M.A. and Ph.D., University of Chicago, 1954 and
1960). Throughout her professional career, her interests remained eclectic. At San Jose State, in addition to teaching courses in American politics and public administration, she experimented with seminars on Shakespeare's politics, the political novel, and politics and drama. She assumed leadership in a series of inter-disciplinary programs--"Tutorials," "New College," American Studies, Women's Studies, and Gerontology. She played a major role in revising general education requirements, edited a campus-based journal, and served on countless timeconsuming committees.

Beyond the campus, she was a founding member of California Women in Higher Education, the Santa Clara County Caucus of the National Women's Political Caucus, Bay Area Women in Political Science, and the National Women's Studies Association. She did research on Presidential press conferences at the Brookings Institution, was a fellow at the Pacific School of Religion, and regularly attended summer sessions of St. John's College's Graduate Institute in Liberal Education at Santa Fe.

Aside from these institutional connections and contributions, she was known and valued for her encouragement and assistance to students, colleagues, and friends. The memorial service held on December 9 , 1995, gave many of us who loved her an opportunity to pay tribute to her kindness, generosity, and sense of humor. We continue to miss her.

Lela Garner Noble San Jose State University 